\title{
PEMETAAN POTENSI PANAS BUMI (GEOTHERMAL) UNTUK MENDUKUNG PROGRAM ENERGI NASIONAL JAWA TIMUR (Studi Kasus : G. Lamongan, Kab. Probolinggo)
}

\author{
Kukuh Danu Permadi, Yuwono \\ Program Studi Teknik Geomatika FTSP-ITS, Kampus ITS Sukolilo, Surabaya, 60111 \\ Email : kukuhdanu@yahoo.com, yuwono@geodesy.its.ac.id
}

\begin{abstract}
Abstrak
Kondisi geologi Indonesia yang terletak pada tiga pertemuan lempeng tektonik memberikan kontribusi nyata akan ketersediaan energi panas bumi di Indonesia. Manifestasi panas bumi yang berjumlah tidak kurang dari 244 lokasi, dari potensi tersebut baru $4 \%$ yang telah dikembangkan. Selain itu dengan adanya MP3EI (Masterplan Percepatan dan Perluasan Pembangunan Ekonomi Indonesia) tahun 2011 diharapkan bisa digunakan sebagai rencana jangka panjang.
\end{abstract}

Pemantauan hasil yang terbaik diperlukan dalam melakukan analisa untuk pengamatan daerah potensi panas bumi. Analisa tersebut menggunakan citra satelit Landsat 7. Dengan menggunakan algoritma NDVI, spectral radiance, brightness temperature, dan laplacian matrix untuk menentukan suatu anomaly dari adanya potensi panas bumi pada daerah penelitian, dengan waktu penelitian pada bulan Jul 2009i. Dengan adanya MP3EI maka akan ada suatu arahan secara nasional dalam pengembangan menuju Indonesia yang lebih sejahtera. Daerah penelitian yang digunakan dalam penelitian ini adalah wilayah Kabupaten Probolinggo dan sekitarnya.

Dari hasil pengolahan data dan analisa didapatkan korelasi antara indeks vegetasi dengan ketinggian bernilai 0.09 , korelasi antara indeks vegetasi dengan suhu permukaan bernilai 0.34 , korelasi antara ketinggian dan suhu permukaan bernilai -0.56. Dari penampakan secara geologi pun terdapat suatu patahan yang membelah lokasi penelitian dan berada di sebelah timur ke utara dimana dari anomaly yang terlihat dari 4 variabel ini menunjukkan adanya potensi panas bumi yang bisa dimanfaat untuk bidang makanan minuman, perkapalandan peralatan transportasi sesuai dengan MP3EI. Uji klasifikasi yang dilakukan bernilai 83,67\%, yang menunjukkan klasifikasi lahan pada citra mempresentasikan kondisi sesungguhnya. Data hasil analisis dapat dijadikan sebagai bahan referensi penelitian selanjutnya.

Kata Kunci : MP3EI, Panas bumi, NDVI, Suhu Permukaan Darat, Penginderaan jauh

\section{PENDAHULUAN}

\section{Latar Belakang}

Indonesia secara geologis terletak pada pertemuan tiga lempeng tektonik utama yaitu : Lempeng Eropa-Asia, India-Australia dan Pasifik yang berperan dalam proses pembentukan gunung api di Indonesia. Kondisi geologi ini memberikan kontribusi nyata akan ketersediaan energi panas bumi di Indonesia. Manifestasi panas bumi yang berjumlah tidak kurang dari 244 lokasi tersebar di P. Sumatera, Jawa, Bali, Kalimantan, Kepulauan Nusa Tenggara, Maluku, P. Sulawesi, Halmahera dan Irian Jaya, menunjukkan betapa besarnya kekayaan energi panas bumi yang tersimpan di dalamnya. (klasifikasi energi panas bumi di Indonesia, SNI, 1998)
Dari potensi tersebut baru $4 \%$ yang telah dikembangkan dan dimanfaatkan terutama untuk pembangkit listrik tenaga panas bumi (PLTP) di wilayah-wilayah dimana kebutuhan energi listrik dari sumber pembangkit konvensional sudah tidak memadai lagi. (Kementrian Perencanaan Pembangunan Nasional, 2010).

Dengan memanfaatkan kelebihan penginderaan jauh yang berupa liputannya yang luas dan berulang-ulang, ketelitian pengamatan yang tinggi dan biaya yang relatif murah untuk persatuan luas, memberikan kemungkinan untuk mengintegrasi tingkat keakurasian dan efisiensi dalam penyediaan data dan informasi panas bumi (geothermal).

Saat ini pun sudah diadakannya program MP3EI (Masterplan Percepatan dan Perluasan 
Pembangunan Ekonomi Indonesia) 2011 - 2025 yang tujuannya adalah memberikan acuan suatu langkah strategis untuk mewujudkan Indonesia mandiri, maju, adil dan makmur.

\section{Perumusan Masalah}

Rumusan masalah dalam penelitian ini adalah :

1. Bagaimana memetakan potensi panas bumi (geothermal) dengan citra Landsat ETM

2. Bagaimana cara mengolah data citra satelit Landsat ETM, sehingga dapat digunakan untuk memetakan daerah yg berpotensi panas bumi dengan mengetahui kenampakan rupa bumi

3. Bagaimana hubungan antara potensi panas bumi yang ada dengan langkah strategis MP3EI

\section{Batasan Masalah}

Batasan masalahan dari penelitian ini adalah:

1. Data citra yang digunakan adalah citra Landsat ETM tahun 2009

2. Wilayah penelitian meliputi Gunung Lamongan dan sekitarnya yang berada di perbatasan Kabupaten Probolinggo dan Lumajang

3. Informasi yang ditampilkan dalam peta panas bumi hasil inderaan jauh diantaranya adalah titik-titik dimana daerah tersebut memiliki potensi panas bumi

\section{Tujuan Penelitian}

Tujuan penelitian ini adalah untuk memetakan titik-titik / daerah potensi panas bumi (geothermal), menganalisa hal-hal yang berkaitan lainnya dengan menggunakan citra Landsat ETM yang diambil pada musim panas yaitu bulan Juli 2009 sebagai upaya pengurangan dampak pemanasan global dan alternatif dalam mencari energi untuk mendukung program MP3EI.

\section{METODOLOGI PENELITIAN}

\section{Lokasi Penelitian}

Lokasi penelitian Tugas Akhir ini mengambil daerah studi di Kabupaten Probolinggo dan sebagian Kabupaten Lumajang. Secara geografis terletak pada koordinat $112^{\circ} 50^{\prime}-113^{\circ} 30^{\prime}$ BT dan $7^{\circ} 40^{\prime}-8^{\circ} 10^{\prime} \mathrm{LS}$, dalam penelitian berada pada posisi pada Gambar 1.

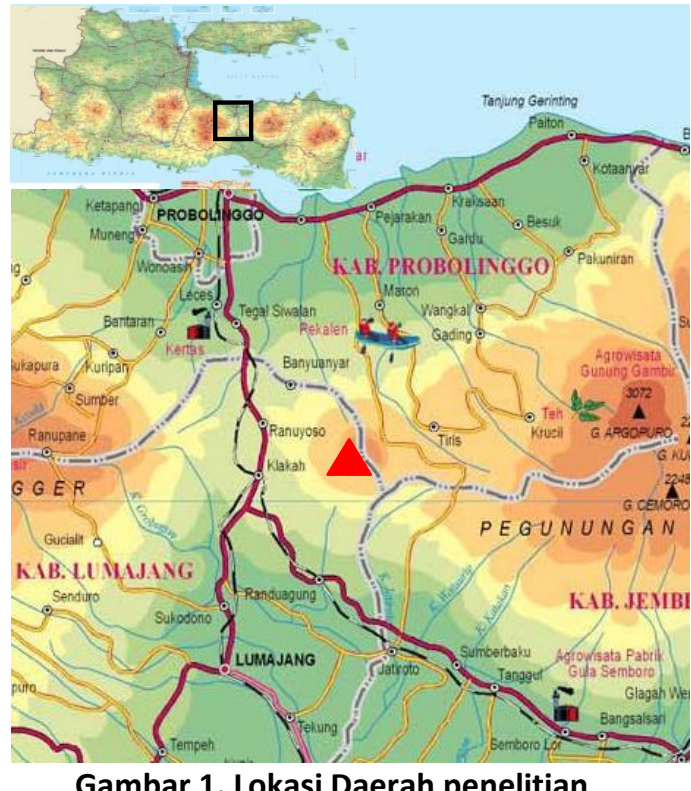

Gambar 1. Lokasi Daerah penelitian

\section{Data Dan Peralatan}

\section{- Data}

Data yang digunakan dalam penelitian ini adalah:

1. Citra Satelit Landsat 7 tanggal 9 Juli 2009 Level $1 \mathrm{G}$

2. Citra Satelit Landsat 7 tanggal 10 Agustus 2009 Level 1G

3. Citra Satelit Landsat 7 tanggal 29 Oktober 2009 Level $1 \mathrm{G}$

4. Citra Satelit Landsat Orthometrik tahun 2002 resolusi 15 meter

5. Peta RBI kabupaten Probolinggo skala 1:25000, lembar Tiris, Klakah, Randuagung, Sumberbaru

6. Data lapangan diambil secara in-situ di beberapa titik lokasi penelitian.

\section{Peralatan}

Peralatan yang digunakan dalam penelitian ini adalah:

1. Perangkat Keras (Hardware)

$$
\text { a. Laptop }
$$

2. Perangkat Lunak (Software)
a. Sistem Operasi Windows 7
b. Microsoft Word 2007 untuk pembuatan laporan
c. Microsoft Excel 2007 untuk pengolahan data tabular
d. Microsoft Visio 2003 untuk pembuatan diagram alir
e. ArcGIS 9.3 untuk pembuatan layout peta.


f. ENVI 4.6.1 untuk pengolahan data citra satelit yaitu proses koreksi geometrik

g. Matlab 7.0 untuk proses perhitungan Strenght of Figure

\section{Diagram Alir Pengolahan Data}

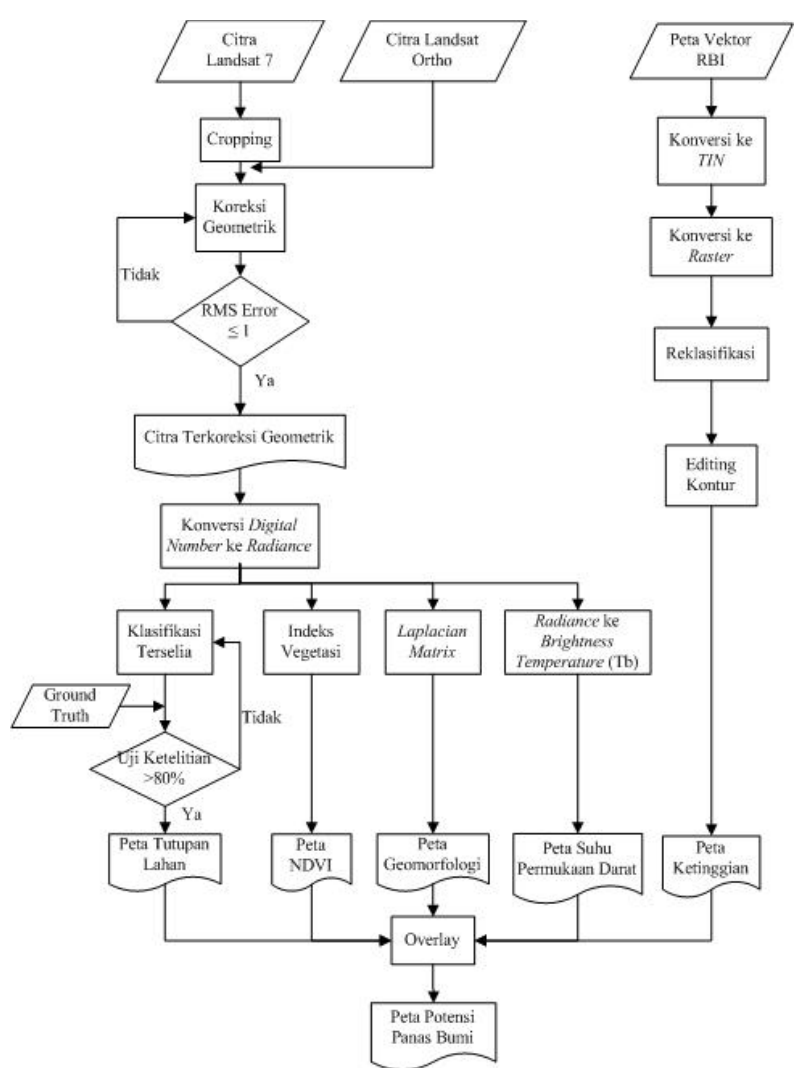

Gambar 2. Diagram Tahap Pengolahan Data

Penjelasan untuk diagram alir diatas adalah:

1. Pengolahan Citra

Algoritma MODIS untuk Klorofil

2. Konversi Nilai Digital Number ke Dalam Nilai Spectral Radiance

Suhu kecerahan dihitung dengan menggunakan nilai spectral radiance yang diperoleh dari nilai digital number USGS (2002), persamaannya adalah :

$$
L_{\lambda}=\frac{\left(L_{\max }-L_{\text {min }}\right)}{\left(Q_{c a l \text { max }}-Q_{c a l \text { min }}\right)}\left(Q_{c a l}-Q_{c a l \text { min }}\right)+L_{\text {min }}
$$

Keterangan:

$$
\begin{array}{ll}
\mathrm{L} \lambda & =\text { Spectral radiance pada band ke } \\
& \mathrm{i}(\mathrm{Wm}-2 \mathrm{sr}-1 \mu \mathrm{m}-1) \\
\text { QCAL } & =\text { Nilai digital number band I ke } \mathrm{i}
\end{array}
$$

LMIN = Nilai minimum spectral radiance band ke $\mathrm{i}$

LMAX = Nilai maximum spectral radiance band ke $\mathrm{i}$

QCALMIN = Minimum pixel value QCALMAX = Maximum pixel value (255)

3. Konversi Nilai Spectral Radiance $(L \lambda)$ ke Dalam Brightness Temperature (TB)

Persamaan yang digunakan mengikuti hubungan yang sama dengan persamaan Planck dengan dua konstanta kalibrasi. Konstanta kalibrasi data citra landsat dengan persamaan sebagai berikut (Qiming Qin, dkk 2011):

$$
T B=\frac{K 2}{\ln \left(\frac{K 1}{L \lambda}\right)+1}
$$

Keterangan :

untuk landsat ETM

$\mathrm{K} 1=666.09 \mathrm{Wm}^{-2} \mathrm{sr}^{-1} \mu \mathrm{m}^{-1}$

$\mathrm{K} 2=1282.71 \mathrm{~K}$

Landsat TM,

$\mathrm{K} 1=607,76 \mathrm{Wm}^{-2} \mathrm{sr}^{-1} \mu^{-1}$

$\mathrm{K} 2=1260.56 \mathrm{~K}$

4. Menghitung Jarak

$$
d=(1-0.01674 \cdot \operatorname{Cos}(0.9856(J D-4)))
$$

Normalized Difference Vegetation Index (NDVI)

$$
\rho=\frac{\pi L_{\lambda} d^{2}}{\operatorname{Esun} \lambda \cos \theta}
$$

Keterangan :

$\rho \quad=\quad$ Unitless Planetary Reflectance

$\mathrm{L} \lambda \quad=$ Spectral Radiance at The Sensor's Aperture

$\mathrm{d}^{2}=$ Earth-Sun Distance in Astronomical Units

ESUN $\lambda=$ Mean Solar Exoatmospheric Irradiances

$\theta=$ Solar Zenith Angle in Degrees

$\pi=3,141592654$

$$
\text { NDVI }=\frac{\text { Rnir-Rred }}{\text { Rnir+Rred }}
$$

Keterangan :

Rnir : Nilai Reflektan kanal inframerah dekat 
Rred : Nilai reflektan kanal merah

\section{HASIL DAN PEMBAHASAN}

\section{Koreksi Geometrik Citra}

Hasil koreksi geometrik pada citra Landsat 7 adalah 0.684 dengan 21 titik kontrol. Hasil RMS rata-rata citra mempunyai nilai RMS rata-rata kurang dari 1 pixel dan SoF mendekati nol sehingga dianggap memenuhi toleransi yang diberikan (Purwadhi, 2001).

\section{a. Hasil Peta}

- Peta Persebaran Vegetasi

- Peta Suhu Permukaan Darat

- Peta Geomorfologi

- Peta Ketinggian Lahan

- Peta Klasifikasi Lahan

( Peta Terlampir)

\section{b. Analisa}

Konversi $D N$ dilakukan dengan mengubah nilai $D N$ ke dalam nilai radian, kemudian dari nilai radian diubah kedalam nilai reflektan.

\section{DN $\rightarrow$ Radian $\rightarrow$ Reflektan}

\section{c. Hasil Pengolahan Citra}

Konversi ini bertujuan untuk mengurangi kesalahan radiometrik pada citra, serta untuk mengolah algoritma indeks vegetasi yang menggunakan data nilai reflektan dari citra.

Tabel 1. Metadata Citra Landsat 7

\begin{tabular}{|c|c|c|c|}
\hline Band & $\begin{array}{l}\text { Panjang } \\
\text { Gelombang } \\
(\mu \mathrm{m})\end{array}$ & Lmax & Lmin \\
\hline Band 1 & $0,45-0,52$ & 191,60 & $-6,20$ \\
\hline Band 2 & $0,52-0,60$ & 196,50 & $-6,40$ \\
\hline Band 3 & $0,63-0,69$ & 152,90 & $-5,00$ \\
\hline Band 4 & $0,76-0,90$ & 241,10 & $-5,10$ \\
\hline Band 5 & $1,55-1,75$ & 31,06 & $-1,00$ \\
\hline Band 7 & $2,08-2,35$ & 10,80 & $-0,35$ \\
\hline Akuisisi Citra & 9 Juli 2009 & & \\
\hline Qcalmax & 255,00 & & \\
\hline Qcalmin & 1,00 & & \\
\hline Sun Azimuth & 45.5730211 & & \\
\hline Sun Elevation & 47.1166690 & & \\
\hline
\end{tabular}

Tabel 2. Solar Irradiance Citra Landsat 7

\begin{tabular}{cc}
\hline Band & $\begin{array}{c}\text { watts/(meter squared } \\
* \boldsymbol{\mu m})\end{array}$ \\
\hline Band 3 & 1551 \\
Band 4 & 1044 \\
\hline
\end{tabular}

Dari data tersebut dapat dihitung nilai Julian Date dari masing-masing akuisisi citra.

Tabel 3. Julian Date

\begin{tabular}{ccc}
\hline Akuisisi & Julian Date & d \\
\hline 9 Juli 2009 & 2455021.601 & 1,0053
\end{tabular}

Dari data tersebut juga dapat dihitung nilai kuadrat jarak matahari.

Tabel 4. Sun Elevation

\begin{tabular}{ccc}
\hline Sun Elevation & $\begin{array}{c}\text { Sudut Zenith } \\
(\boldsymbol{\theta})\end{array}$ & $\operatorname{Cos}(\boldsymbol{\theta})$ \\
\hline 47.1166690 & 42.883331 & 0.732740909
\end{tabular}

\section{Ketinggian Lahan}

Informasi ketinggian lahan diperoleh dari data vektor peta $\mathrm{RBI}$, peta vector $\mathrm{RBI}$ kemudian dibuat data DEM, file DEM tersebut dikonversikan ke grid, Setelah dikonversikan, data tersebut direklasifikasi sesuai dengan kelas ketinggian yang telah ditentukan

Tabel 5. Kelas Ketinggian

\begin{tabular}{ll}
\hline No & \multicolumn{1}{c}{ Kelas Ketinggian $(\mathbf{m})$} \\
\hline 1 & $12,5-194.444$ \\
2 & $194.444-376.389$ \\
3 & $376.389-558.333$ \\
4 & $558.333-740.278$ \\
5 & $740.278-922.222$ \\
6 & $922.222-1104.167$ \\
7 & $1104.167-1286.111$ \\
8 & $1286.111-1488.056$ \\
9 & $1488.056-1650$ \\
\hline
\end{tabular}

\section{Indeks Vegetasi}

Tabel 6. Kisaran Tingkat Kerapatan NDVI (Sumber Departemen Kehutanan, 2003)

\begin{tabular}{llc}
\hline Kelas & Kisaran NDVI & $\begin{array}{c}\text { Tingkat } \\
\text { Kerapatan }\end{array}$ \\
\hline 1 & $-1,0$ s.d 0,32 & Jarang \\
2 & 0,32 s.d 0,42 & Sedang \\
3 & $>0,42$ s.d 1 & Tinggi \\
\hline
\end{tabular}

Tabel 7. Hasil pengelompokkan nilai vegetasi

\begin{tabular}{ccc}
\hline No & Kelas NDVI & Kerapatan Vegetasi \\
\hline 1 & $-0,7868-(-0,5807)$ & Jarang \\
2 & $-0,5807-(-0,3747)$ & Jarang \\
3 & $-0,3747-(0,1688)$ & Jarang \\
4 & $-0,1688-0,0372$ & Jarang \\
5 & $0,0372-0,2432$ & Jarang \\
6 & $0,2432-0,4492$ & Sedang \\
7 & $0,4492-0,6552$ & Tinggi \\
8 & $0,6552-0,8611$ & Tinggi \\
\hline
\end{tabular}


Daerah potensi sumber daya panasbumi di Indonesia umumnya berada di kawasan hutan lindung, hutan konservasi, dan cagar alam, dengan permukaan area sebagian besar tertutup vegetasi. Pantulan vegetasi secara umum menunjukkan nilai kecerahan yang tinggi pada panjang gelombang inframerah pantulan. Oleh karena itu anomali vegetasi pada area panas bumi perlu dikaji sebagai indikator adanya sumberdaya panasbumi di area tersebut. Indikator permukaan area panas bumi adalah mineral permukaan, alterasi hidrotermal, vegetasi, dan anomali termal. (Bujung, Cyrke A.N. dkk. 2010)

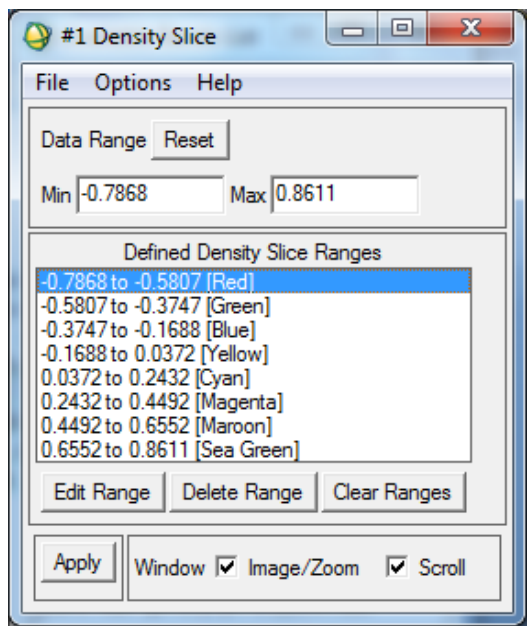

Gambar 3. Nilai density slice NDVI

\section{Suhu Permukaan Darat}

Suhu permukaan darat merupakan kenampakan rata-rata dari suhu yang berada di permukaan tersebut. Pada umumnya, semakin tinggi daerah tertentu, maka suhu permukaan daratnya akan semakin menurun. Hal ini karena Karakteristik dari adalah terjadinya penurunan suhu dengan adanya kenaikan altitude, dengan adanya penambahan jarak dari radiasi panas bumi. (vertical thermal structure of the atmosphere).

Salah satu prospek dari manifestasi panas bumi adalah terdapat suatu anomali dari hasil pengolahan suhu permukaan dibandingkan dengan daerah disekitarnya. Hal ini dicurigai sebagai kawasan tempat keluarnya fluida panas dari reservoir ke permukaan. (Wahyudi, 2005).

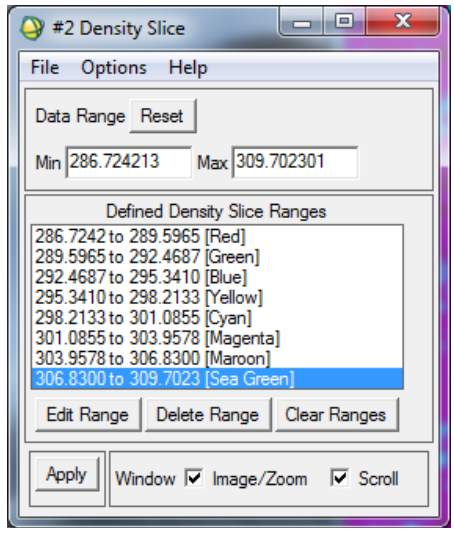

Gambar 4. Nilai Density Slice Suhu Permukaan

\section{Struktur Geologi}

Interpretasi struktur geologi dilakukan dengan analisis kelurusan pada peta topografi serta mengambil data rekahan dan sesar di lapangan. Struktur geologi yang berkembang di daerah penelitian pada umumnya berarah NW-SE (barat-laut - tenggara). Struktur sesar naik mengiri (sinistral) dengan bidang N 163 E/ 79o SW, terdapat di daerah Tiris, tepatnya di Sungai Tancak. Dari hal ini dapat ditarik kesimpulan bahwa manifestasi dipengaruhi oleh struktur geologi sehingga bisa mencapai permukaan. Sesar ini memotong satuan piroklastik (breksi) Argopuro dan piroklastik Lamongan. (Tim eksplorasi gunung api lamongan Dinas ESDM, 2010)

Dari hasil convolution laplace band 4 maka terdapat dua sesar patahan besar membujur dari utara ke selatan melewati kawasan Gunung Lamongan dan di sebelah utra timur yang diperkirakan merupakan struktur yang mengontrol keberadaan manifestasi panas bumi di kawasan ini.

\section{Uji Klasifikasi}

Uji ketelitian dilakukan untuk mengetahui ketelitian hasil klasifikasi, metode yang digunakan pada pengolahan ini yaitu perhitungan confusion matrix dengan menggunakan software ENVI 4.6. Sebelum melakukan uji ketelitian, dilakukan groundtruth atau cek lapangan untuk mengecek kebenaran hasil klasifikasi citra dengan kenampakan obyek di lapangan.

Pada penelitian ini jumlah titik sampel yang dibandingkan berjumlah 30 titik. Selanjutnya titik sampel tersebut diproses confusion matrix. 
Jika hasil perhitungan confusion matrix $\geq 80 \%$ maka klasifikasi citra dianggap benar ((Short, 1982) dalam Purwadhi 2001). Dari hasil perhitungan confusion matrix yang sudah dilakukan, didapatkan hasil ketelitian seluruh hasil klasifikasi $(\mathrm{KH})$ sebesar $83,67 \%$.

\section{Uji Korelasi}

Penentuan analisis korelasi dilakukan dengan cara mengambil secara acak sebanyak 15 titik sampel yang mewakili penyebaran indeks vegetasi pada berbagai kelas ketinggian dan suhu permukaan

Tabel 8. Tingkat hubungan korelasi (Pedoman Interpretasi Koefisien Korelasi (Sugiyono, 2007)

$$
\begin{array}{cc}
\hline \text { Interval koefisien } & \begin{array}{c}
\text { Tingkat } \\
\text { Hubungan }
\end{array} \\
\hline 0,00-0,199 & \text { Sangat rendah } \\
0,20-0,339 & \text { Rendah } \\
0,40-0,599 & \text { Sedang } \\
0,60-0,799 & \text { Kuat } \\
0,80-1,00 & \text { Sangat Kuat } \\
r=\frac{n \sum X_{i} Y_{i}-\left(\sum X_{i}\right)\left(\sum Y_{i}\right)}{\sqrt{\left\{n \sum X_{i}^{2}-\left(\sum X_{i}\right)^{2}\right\}\left\{n \sum Y_{i}^{2}-\left(\sum Y_{i}\right)^{2}\right\}}}
\end{array}
$$

Keterangan:

$r \quad=$ koefisien korelasi

$\mathrm{n}$ = banyaknya pengamatan

$X_{i}=$ Nilai variabel untuk indeks vegetasi

$Y_{i}=$ Nilai variabel untuk ketinggian dan kemiringan lahan.

(Usman dan Akbar,2006)

Tabel 9. Korelasi Indeks Vegetasi dngan Ketinggian Lahan

\begin{tabular}{|c|c|c|c|}
\hline \multicolumn{4}{|c|}{ Korelasi } \\
\hline $\begin{array}{l}\text { Landsat } \\
\text { ETM }\end{array}$ & 7 & Pearson Correlation & -0.56 \\
\hline
\end{tabular}

\begin{tabular}{lll}
\hline \multicolumn{2}{c}{ Korelasi Ketinggian Lahan } \\
\hline Landsat 7 ETM Pearson Correlation & 0,09 \\
\hline
\end{tabular}

Tabel 10. Korelasi Indeks Vegetasi dengan Suhu Permukaan

\begin{tabular}{lll}
\hline \multicolumn{3}{c}{ Korelasi Suhu Permukaan } \\
\hline Landsat 7 ETM $\quad$ Pearson Correlation & 0,34 \\
\hline
\end{tabular}

Tabel 11. Korelasi Ketinggian dan Suhu Permukaan
Koefisien korelasinya bertanda $(+)$, artinya hubungan ketinggian tempat dengan indeks vegetasi satu arah, itu berari semakin tinggi suatu titik, maka vegetasinya akan semakin lebat. Jika koefisien korelasinya bertanda (-), artinya hubungan suhu permukaan dengan ketinggian berkebalikan arah, dimana semakin tinggi suatu titik maka suhu akan semakin rendah.

\section{KESIMPULAN DAN SARAN}

\section{Kesimpulan}

Berdasarkan hasil penelitian tentang pemetaan hutan menggunakan algoritma NDVI dan EVI, maka didapatkan beberapa kesimpulan akhir dari penelitian ini, yaitu:

1. Nilai indeks vegetasi tersebar hampir diseluruh kelas ketinggian, nilai indeks vegetasi yang mendominasi untuk NDVI Landsat 7 ETM pada rentang $-0,7868$ 0,8611 .

2. Penutup lahan yang ada di daerah penelitian memiliki 8 jenis tutupan lahan, yaitu badan air, pemukiman, hutan, kebun, ladang, semak, sawah, tanah kosong dengan nilai uji klasifikasi $83,67 \%$ dengan nilai RMS error 0,6843 dan SOF 0,1594

3. Hasil korelasi antara indeks vegetasi dengan ketinggian termasuk korelasi sangat rendah $(0,00-0,199)$. Koefisien korelasinya bertanda (+), artinya hubungan ketinggian tempat dengan indeks vegetasi satu arah, sehingga jika ketinggian semakin tinggi, maka nilai indeks vegetasi juga semakin tinggi. Hasil korelasi antara indeks vegetasi dengan suhu permukaan termasuk tingkat korelasi rendah $(0,20-0,399)$. Hasil korelasi antara ketinggian dengan suhu permukaan termasuk tingkat korelasi sedang $(-0,40-$ 0,599).

4. Hasil pemanfaatan panas bumi daerah jawa timur digunakan sesuai dengan MP3EI. Maka Pulau Jawa dikhususkan untuk pendorong industri dan jasa nasional dimana meliputi bidang peralatan transportasi, perkapalan, dan makanan minuman

5. Terdapat 2 sesar/kelurusan batuan dimana menjadi penanda dari potensi panas bumi ini berada. Selain itu ditambah dengan adanya anomali dari suhu permukaan darat 
daerah gunung lamongan di bagian utara dan di bagian utara timur dan nilai vegetasi.

\section{Saran}

1. Untuk penelitian selanjutnya dapat diketahui bahwa indikator permukaan area panas bumi adalah mineral permukaan, alterasi hidrotermal, vegetasi, dan anomali termal. Oleh karena itu perlu melihat kembali variabel yang belum dianalisis seperti semineral permukaan, alterasi hidrotermal, titik panas (hot spot), dan penelitian secara geofisika

2. Saat ini untuk menganalisis adanya potensi panas bumi hanya terbatas pada survey geologi dan geokimia, maka kedepannya perlu diadakan survey secara geofisika

\section{DAFTAR PUSTAKA}

LillesandT.M., and Kiefer R.W. 1994. Remote Sensing and Image Interpretation. Second Edition. New York: John Willey \& Sons.

Maryantika, Norida. 2011. Analisa Perubahan Vegetasi Lahan Ditinjau dari Tingkat Ketinggian dan Kemiringan Lahan Menggunakan Citra Satelit Landsat dan Spot 4 Studi Kasus Kabupaten Pasuruan. Tugas Akhir Prgram Studi Teknik Geomatika Fakultas Teknik Sipil dan Perencanaan. Surabaya: Institut Teknologi Sepuluh Nopember.
Badan Standardisasi Nasional. 1998. Klasifikasi Potensi Energi Panas Bumi di Indonesia. SNI 13-5012-1998. Jakarta

Bujung, Cyrke A.N. dkk. 2010. Karakteristik Spektral Permukaan Daerah Panas Bumi Studi kasus di Daerah Panas Bumi Patuha Jawa Barat.

Kementrian Koordinator Bidang Perekonomian. 2011. Masterplan Percepatan dan Perluasan Pembangunan Ekonomi Indonesia. Jakarta: Kementrian Koordinator Bidang Perekonomian.

Peraturan Presiden RI. 2010. Rencana Pembangunan Jangka Menengah Nasional. Jakarta: Kementrian Perencanaan Pembangunan Nasional.

Purwadhi, Sri Hardiyanti.2001. Interpretasi Citra Digital. Jakarta: PT Gramedia Widiasarana

Qin, Qiming dkk. 2011. Geothermal Area using Landsat ETM+ Thermal Infrared Data and its Mechanistic Analysis, case study in Tengchong, China

Sugiyono. 2007. Hipotesis Statistik. Bandung: Universitas Pendidikan Indonesia.

Usman, Husaini dan Purnomo, Setiadi Akbar. 2006. Pengantar Statistik. Jakarta: PT. Bumi Aksara.

Wahyudi. 2005. Kajian Potensi Panas Bumi Dan Rekomendasi Pemanfaatannya Pada Daerah Prospek Gunungapi Ungaran Jawa Tengah. Jurusan Fisika, FMIPAUGM, Yogyakarta 


\section{LAMPIRAN}

\section{Peta Persebaran NDVI}

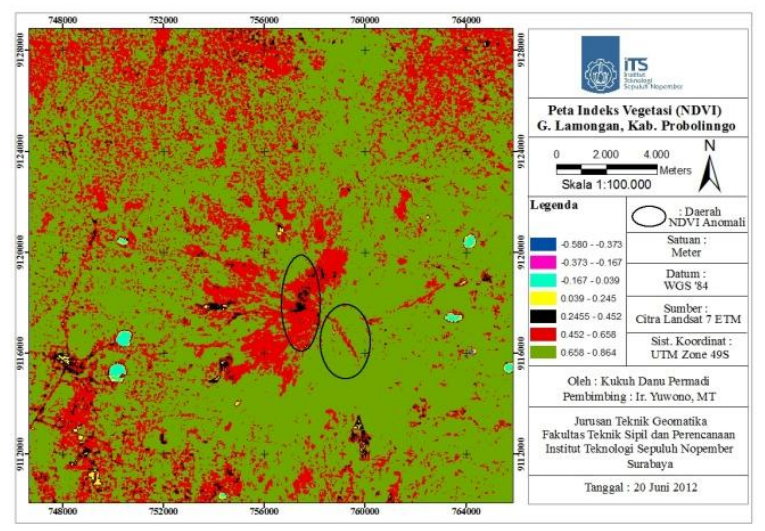

\section{Peta Geomorfologi}

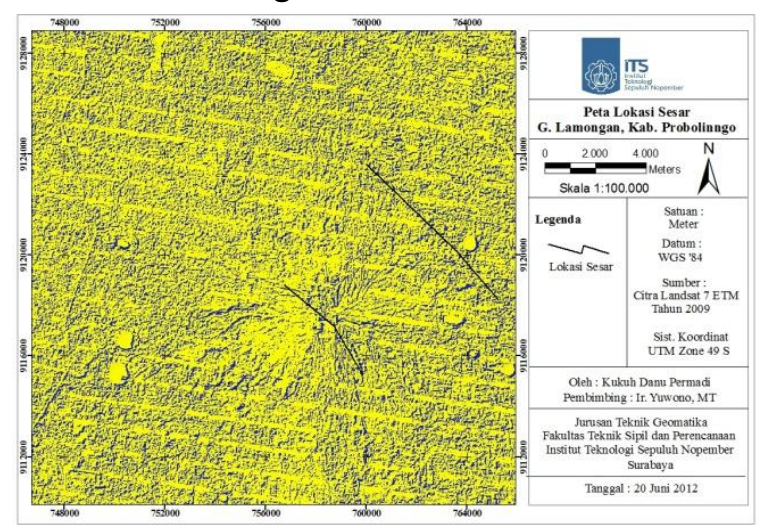

Peta Suhu Permukaan Darat

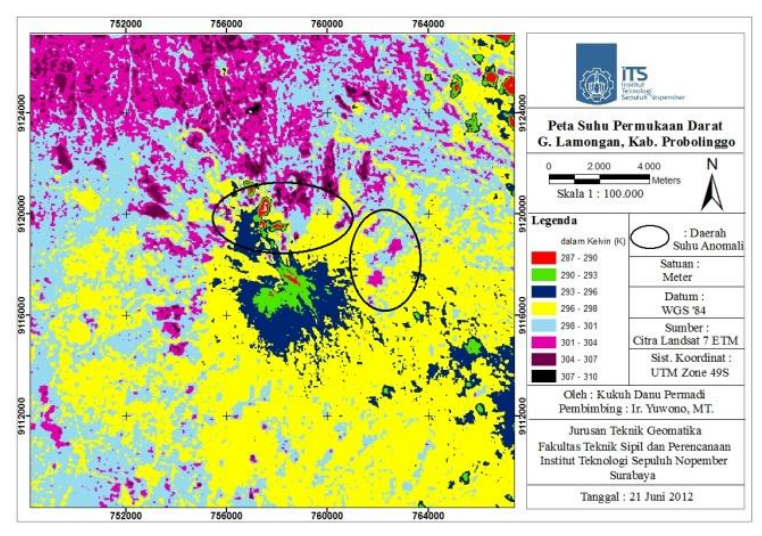

\section{Peta Klasifikasi Lahan}

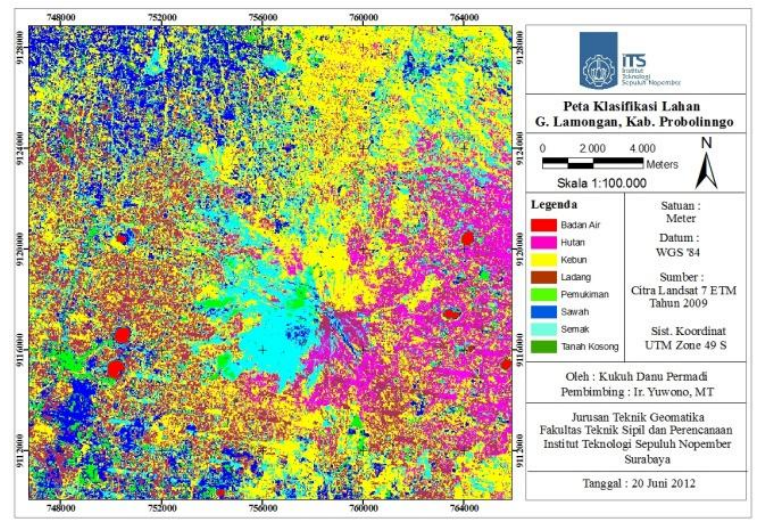

\section{Peta Ketinggian Lahan}

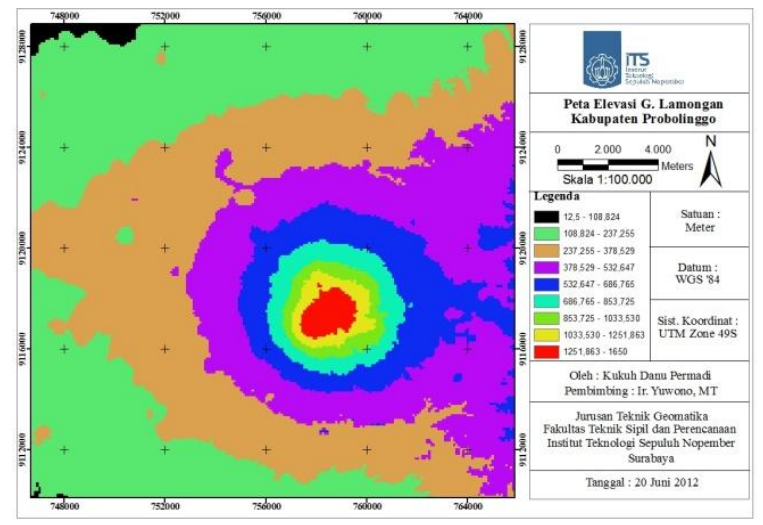




\section{LAMPIRAN}

Hasil Uji Klasifikasi

Overall Accuracy $=(651 / 778) 83.6761 \%$

Kappa Coefficient $=0.7864$

Grountruth (pixels)

\begin{tabular}{llllllllll}
\hline Class & Kebun & Semak & Hutan & Ladang & $\begin{array}{l}\text { Tanah } \\
\text { Kosong }\end{array}$ & $\begin{array}{l}\text { Pemuki } \\
\text { man }\end{array}$ & Sawah & $\begin{array}{l}\text { Badan } \\
\text { Air }\end{array}$ & Total \\
\hline Kebun & 23 & 29 & 10 & 0 & 0 & 0 & 0 & 0 & 62 \\
Semak & 8 & 0 & 0 & 1 & 0 & 0 & 0 & 0 & 9 \\
Hutan & 4 & 0 & 276 & 29 & 0 & 0 & 0 & 0 & 309 \\
Ladang & 13 & 0 & 17 & 144 & 0 & 0 & 0 & 0 & 174 \\
T. Kosong & 0 & 0 & 0 & 0 & 20 & 0 & 0 & 0 & 20 \\
Pemukiman & 0 & 0 & 0 & 0 & 0 & 54 & 0 & 0 & 54 \\
Sawah & 15 & 0 & 0 & 1 & 0 & 0 & 87 & 0 & 103 \\
Badan Air & 0 & 0 & 0 & 0 & 0 & 0 & 0 & 47 & 47 \\
Total & 63 & 29 & 303 & 175 & 20 & 54 & 87 & 47 & 778 \\
\hline
\end{tabular}

Grountruth (percent)

\begin{tabular}{llllllllll}
\hline Class & Kebun & Semak & Hutan & Ladang & $\begin{array}{l}\text { Tanah } \\
\text { Kosong }\end{array}$ & $\begin{array}{l}\text { Pemuki } \\
\text { man }\end{array}$ & Sawah & $\begin{array}{l}\text { Badan } \\
\text { Air }\end{array}$ & Total \\
\hline Kebun & 36.51 & 100 & 3.30 & 0 & 0 & 0 & 0 & 0 & 7.97 \\
Semak & 12.70 & 0 & 0 & 0.57 & 0 & 0 & 0 & 0 & 1.16 \\
Hutan & 6.35 & 0 & 91.09 & 16.57 & 0 & 0 & 0 & 0 & 39.72 \\
Ladang & 20.63 & 0 & 5.61 & 82.29 & 0 & 0 & 0 & 0 & 22.37 \\
T. Kosong & 0 & 0 & 0 & 0 & 100 & 0 & 0 & 0 & 2.57 \\
Pemukiman & 0 & 0 & 0 & 0 & 0 & 100 & 0 & 0 & 6.94 \\
Sawah & 23.81 & 0 & 0 & 0.57 & 0 & 0 & 100 & 0 & 13.24 \\
Badan Air & 0 & 0 & 0 & 0 & 0 & 0 & 0 & 100 & 6.04 \\
Total & 100 & 100 & 100 & 100 & 100 & 100 & 100 & 100 & 100 \\
\hline
\end{tabular}

\begin{tabular}{|c|c|c|c|c|c|c|c|c|}
\hline Class & $\begin{array}{l}\text { Commission } \\
\text { percent }\end{array}$ & $\begin{array}{l}\text { Omission } \\
\text { percent }\end{array}$ & $\begin{array}{l}\text { Commission } \\
\text { pixels }\end{array}$ & $\begin{array}{l}\text { Omission } \\
\text { pixels }\end{array}$ & $\begin{array}{l}\text { Prod. } \\
\text { Acc. } \\
\text { percent }\end{array}$ & $\begin{array}{l}\text { User } \\
\text { Acc } \\
\text { percent }\end{array}$ & $\begin{array}{l}\text { Prod. } \\
\text { Acc. } \\
\text { pixels }\end{array}$ & $\begin{array}{l}\text { User } \\
\text { Acc. } \\
\text { pixels }\end{array}$ \\
\hline Kebun & 62.90 & 63.49 & $39 / 62$ & $40 / 63$ & 36.51 & 37.10 & $23 / 63$ & $23 / 62$ \\
\hline Semak & 100.00 & 100.00 & $9 / 9$ & $29 / 29$ & 0 & 0 & $0 / 29$ & $0 / 9$ \\
\hline Hutan & 10.68 & 8.91 & $33 / 309$ & $27 / 303$ & 91.09 & 89.32 & $276 / 303$ & $276 / 309$ \\
\hline Ladang & 17.24 & 17.71 & $30 / 174$ & $31 / 175$ & 82.29 & 82.76 & $144 / 175$ & $144 / 174$ \\
\hline T. Kosong & 0 & 0 & $0 / 20$ & $0 / 20$ & 100 & 100 & $20 / 20$ & $20 / 20$ \\
\hline Pemukiman & 0 & 0 & $0 / 54$ & $0 / 54$ & 100 & 100 & $54 / 54$ & $54 / 54$ \\
\hline Sawah & 15.53 & 0 & $16 / 103$ & $0 / 87$ & 100 & 84.47 & $87 / 87$ & $87 / 103$ \\
\hline Badan Air & 0 & 0 & $0 / 47$ & $0 / 47$ & 100 & 100 & $47 / 47$ & $47 / 47$ \\
\hline
\end{tabular}

Keterangan :

Omission : Jumlah kelas $\mathrm{X}$ yang masuk kelas lain

Commission : Jumlah kelas $\mathrm{X}$ tambahan dari kelas lain 